\title{
Gibberellic Acid Alters Sucrose, Hexoses, and Their Gradients in Peel Tissues During Color Break Delay in 'Hamlin' Orange
}

\author{
Matthew W. Fidelibus \\ Department of Viticulture and Enology, University of California, Davis, CA 95616
}

\author{
Karen E. Koch and Frederick S. Davies ${ }^{1}$ \\ Department of Horticultural Sciences, University of Florida, P.O. Box 110690, Gainesville FL 32611
}

\begin{abstract}
AdDitional INDEX words. Citrus sinensis, sugars, carbohydrates, plant growth regulators
Abstract. We investigated the effect of gibberellic acid $\left(\mathrm{GA}_{3}\right)$ application before color break on peel color, fruit respiration, and soluble sugars in different tissues of 'Hamlin' sweet orange [Citrus sinensis (L.) Osb.] fruit to test the hypothesis that $\mathrm{GA}_{3}$ influence on peel color might be mediated by sugars. Fruit were sprayed with $\mathrm{GA}_{3}\left(45 \mathrm{~g} \cdot \mathrm{ha}^{-1}\right.$ a.i.) in early October of 2 consecutive years. Peel color, whole-fruit respiration, and fructose, glucose, and sucrose levels were quantified in flavedo and albedo tissues when nontreated fruit were still green, at precolor break, color break, and when peels were fully yellow. Fruit treated with $\mathrm{GA}_{3}$ remained more green-colored than nontreated fruit, and differences between them were detectable by 12 or 21 days after treatment (Years 1 and 2, respectively). Fruit respiration rates were similar in both groups regardless of peel color. Effects of $\mathrm{GA}_{3}$ on color transition were evident only after significant differences emerged in flavedo glucose (both years) and fructose (second year) levels. Moreover, there was a linear, inverse relationship between green peel color and flavedo fructose $\left(r^{2}=0.68\right.$, first year; 0.72 , second year) and glucose levels $\left(r^{2}=\mathbf{0 . 6 0}\right.$, first year; 0.50 , second year). In contrast, sucrose levels in the flavedo showed a less consistent relationship with peel color. The $\mathrm{GA}_{3}$ treatment maintained a descending sucrose gradient from the albedo to the flavedo that was typical of young, photosynthetically active fruit. This gradient dissipated during peel color change of nontreated fruit. These data support the hypothesis that soluble sugars could be contributing effectors of the $\mathrm{GA}_{3}$-mediated delay in chloroplast-to-chromoplast conversions by the orange flavedo.
\end{abstract}

Flavedo color is an important determinant of citrus fresh fruit quality in many citrus-growing regions worldwide (Davies, 1986). In the fall or winter in subtropical climates, the colored portion of the peel (flavedo) of sweet orange fruit changes color from green to orange as part of a nonclimacteric phase of fruit development. This process, known as color break, involves conversion of chloroplasts to chromoplasts (Huff, 1984) and extensive changes in associated gene expression (Fujii et al., 2008; Goudeau et al., 2008; Rodrigo and Zacarias, 2007). Regulation of color break is not fully understood, but the process can be stimulated by low temperatures (Erickson, 1968) and by rising levels of peel sugars (Goldschmidt and Koch, 1996; Huff, 1984; Iglesias et al., 2001). The temperature and sugar influence may also be related, because low temperature $\left(5{ }^{\circ} \mathrm{C}\right)$ can increase both invertase activity and levels of reducing sugars in the grapefruit (Citrus paradisi Macf.) flavedo (Purvis and Rice, 1983). Plant hormones such as ethylene and gibberellic acid $\left(\mathrm{GA}_{3}\right)$ can also enhance or delay the progression of color break (Iglesias et al., 2001; McCollum and Maul, 2007; Rodrigo and Zacarias, 2007), again with involvement of sugars (Iglesias et al., 2001).

Peel sugars have long been implicated as potential effectors of color break. Soluble sugars in the peel were initially found to correspond with color break in 'Valencia' sweet orange by Huff (1984). He also observed that peel pieces in culture will degreen when supplemented with sucrose and regreen when sucrose is withheld. Likewise, regreening of 'Valencia' orange, which occurs in the spring (Thomson et al., 1967), is preceded by a

Received for publication 27 Aug. 2008. Accepted for publication 3 Oct. 2008. ${ }^{1}$ Corresponding author. E-mail: fsd@ufl.edu. decrease in peel soluble sugars (Huff, 1984). Iglesias et al. (2001) also demonstrated that time of color break can be advanced if sugar levels in the peel are increased by stem injections of sucrose. Each of these observations is consistent with known effects of soluble sugars, especially hexoses, on downregulation of genes encoding chlorophyll and photosynthetic enzymes (Koch, 1996; Pourtau et al., 2006; Price et al., 2004; Rolland et al., 2006).

Gibberellic acid can be applied to citrus fruit in the late summer or fall to improve peel integrity and extend the harvest season (Coggins, 1969; Fidelibus et al., 2002; McDonald et al., 1997). However, such applications also retard color break, and the resulting green peel color may delay harvest. Because peel color is an important factor determining citrus fresh fruit quality (Davies, 1986), it is desirable to better understand the physiology of color break and of $\mathrm{GA}_{3}$ effects on fruit peel color.

The mechanism by which $\mathrm{GA}_{3}$ delays color break remains unclear despite evidence for involvement of sugars (Goldschmidt and Koch, 1996; Huff, 1984; Iglesias et al., 2001) and apparent ethylene interaction (Goldschmidt et al., 1977; Iglesias et al., 2001). There are several potentially overlapping hypotheses for these observations. One is that sugar levels could affect the extent of ethylene production by the citrus peel and that $\mathrm{GA}_{3}$ treatments might repress subsequent responses (Iglesias et al., 2001). Another is that ethylene effects need not necessarily involve sugars, because ethylene-releasing agents can alter peel color without apparent changes in peel sugars (Alferez et al., 2006). Still another possibility is that sugars could influence color break by other means, both direct and indirect (Goldschmidt and Koch, 1996; Huff, 1984; Koch, 1996; Loreti et al., 2008; Lu et al., 2002; Pourtau et al., 2006), 
and that $\mathrm{GA}_{3}$ may exert at least some of its effects by altering levels of peel sugars.

Several lines of evidence provide initial support for the hypothesis that sugars can mediate at least some effects of $\mathrm{GA}_{3}$ on color break. First, the series of studies noted previously describe a close, potentially causal relationship between peel sugars and color break in nontreated fruit. In each of these instances, sugar depletion is associated with a greener flavedo color (Huff, 1984; Iglesias et al., 2001; Thomson et al., 1967). Second, $\mathrm{GA}_{3}$ can alter sugar metabolism in diverse plant systems. These range from actively photosynthesizing leaves where $\mathrm{GA}_{3}$ can enhance sucrose-P synthase (SPS) activity (Cheikh et al., 1992) and expanding fruit where $\mathrm{GA}_{3}$ can increase invertase activity (Cano-Medrano and Darnell, 1997; Estruch and Beltran, 1991; Perez and Gomez, 2000) to aleurone and endosperm of germinating grains where $\mathrm{GA}_{3}$ can induce alpha-amylase (Lu et al., 2002). Citrus flavedo tissue could well be among these, especially because $\mathrm{GA}_{3}$ can alter expression of photosynthetic genes in mandarin fruit (Fujii et al., 2008). Third, multiple mechanisms have now been described that could link $\mathrm{GA}_{3}$-altered sugar composition to associated delays in color break. Among these is a hexose-sensing system that cannot only mediate sugar effects on photosynthetic genes and chlorophyll pigments (Koch, 1996; Pourtau et al., 2006; Rolland et al., 2006), but also on synthesis and perception of hormones such as abscisic acid (ABA) (Rognoni et al., 2007). More direct roles of $\mathrm{GA}_{3}$ in sugar signaling are also possible given the common site of action for both $\mathrm{GA}_{3}$ and sugar depletion in the upstream regulatory sequences of genes such as alpha-amylase (Lu et al., 2002). Evidence also indicates opposing crosstalk between signaling systems for $\mathrm{GA}_{3}$ and sucrose in Arabidopsis thaliana (L.) Heynh. (Loreti et al., 2008). Finally, current models of plastid signaling to the nucleus (relevant to chloroplast-chromoplast interconversions) involve at least three paths, and sugars can affect common constituents of all three (Koussevitzky et al., 2007).

Application of $\mathrm{GA}_{3}$ can affect not only citrus fruit peel color, but may also alter juice sugar levels [soluble solids concentration (SSC)] (Coggins et al., 1960; Fidelibus et al., 2002; Pozo et al., 2000). In some instances, application rates (Coggins et al., 1960) and times (Fidelibus et al., 2002) that best maintain green peel color can also limit accumulation of juice SSC. Data from earlier work are consistent with a role for the albedo (inner peel) as a transient sink or reservoir for sucrose en route to juice sacs during late-season fruit development (Koch and Avigne, 1990; Yen and Koch, 1990). If $\mathrm{GA}_{3}$ action were to alter levels or transit time for sugars in the albedo, then this effect could extend to changes in juice SSC.

This study was conducted to test whether $\mathrm{GA}_{3}$ application to sweet orange fruit affected composition and quantity of soluble sugars in different tissues, and if so, whether timing and sites of change were consistent with a role for soluble sugars in $\mathrm{GA}_{3}$ effects on color break.

\section{Materials and Methods}

Plant material. Fruit used in this study were from mature 'Hamlin' sweet orange [Citrus sinensis (L.) Osb.] trees grown in Gainesville, FL (2000) or Groveland, FL (2001). Trees in Gainesville were 17 years old and budded on sour orange (Citrus aurantium L.) rootstock. Trees in Groveland were $\approx 20$ years old and budded on Carrizo citrange [C. sinensis $\times$ Poncirus trifoliata (L.) Raf.] rootstock.

Gibberellic ACID TREATMENT. Each year, four trees were selected based on uniformity of size, vigor, cropload, and position in the grove. Two west-facing branches bearing a similar amount of fruit were chosen on each tree. One branch per tree was randomly selected for $\mathrm{GA}_{3}$ treatment and another as a nontreated control. The $\mathrm{GA}_{3}$ was applied at $45 \mathrm{~g} \cdot \mathrm{ha}^{-1}$ a.i. from a 4\% (w/v) solution (ProGibb; Valent, Libertyville, IL) containing an organosilicone surfactant $(0.05 \%$, v/v, Silwet; Helena Chemical Corp., Memphis, TN) (Fidelibus et al., 2002) and delivered to fruit and foliage of the treated branch with a handheld sprayer (Solo, Newport News, VA) until runoff. Nontreated branches were protected by plastic sheeting during $\mathrm{GA}_{3}$ application. Treatment dates were 6 Oct. 2000 and 2 Oct. 2001.

FruIt SAMPLING, COLOR QUANTIFICATION, AND RESPIRATION MEASUREMENTS. Five fruit per branch were harvested from treated and nontreated branches when nontreated fruit were still mostly green $(\mathrm{G})$ or at precolor break (PCB), color break (CB), or when fully yellow (Y). Harvest dates were as follows; G, 2 d after treatment, 2000 and 2001; PCB, 7 d after treatment, 2001; CB, $12 \mathrm{~d}$ after treatment, 2000, $21 \mathrm{~d}$ after treatment, 2001; and Y, $54 \mathrm{~d}$ after treatment, 2000, $58 \mathrm{~d}$ after treatment, 2001. Immediately after harvest, fruit were surface-sterilized by gently washing them in a $10 \%$ solution of sodium hypochlorite. The fruit surfaces were air-dried, weighed, and peel color was measured with a chromometer (Minolta, Ramsey, NJ) (Fidelibus et al., 2002). Degree of greenness was represented by increasing values for hue angle. Each five-fruit sample was transferred to a 5-L glass jar and stored in the dark at $20{ }^{\circ} \mathrm{C}$ and $80 \%$ relative humidity for $24 \mathrm{~h}$. The jars were then sealed for $1 \mathrm{~h}$, and respiration rate was calculated from the $\mathrm{CO}_{2}$ in the headspace as measured by a gas chromatograph (Gow-Mac Instrument, Bridgewater, NJ).

Carbohydrate analysis. After fruit respiration measurements were made, separate samples of flavedo and albedo tissues were collected from each set of fruit. In Year 1, three peel discs ( $1.27 \mathrm{~cm}$ diameter) were removed from the equator of each fruit in the five-fruit samples from three of the four trees per treatment. The three trees were randomly selected for season-long analyses of fruit sugars at each harvest date. In Year 2, 10 peel discs per fruit were excised from all four of the five-fruit samples during the first three harvests. However, to accommodate juice samples from the fourth harvest, only three of the five-fruit samples were analyzed for sugars. Flavedo tissue was separated from the albedo with a scalpel and was immediately frozen in liquid nitrogen and stored at $-80^{\circ} \mathrm{C}$ until further analysis. In Year 1, a 2.5-cm length of pulp segment underlying each peel sample was removed with a scalpel and frozen in liquid nitrogen. In the next year, juice was extracted from the fruit with a reamer and stored at $-20{ }^{\circ} \mathrm{C}$ until further analysis.

Each sample of frozen tissue was ground with a mortar and pestle to a fine powder in liquid nitrogen and prepared for analysis by high-pressure liquid chromatography (HPLC) following the methods of Baldwin et al. (1991). The powdered sample was homogenized and a 5-g subsample was added to $10 \mathrm{~mL}$ of $80 \%$ ethanol, boiled for $15 \mathrm{~min}$ (with a loose-fitting cover), cooled, and vacuum-filtered through Whatman \#4 filter paper. For removal of additional particulate, phenolic, or other interfering materials, the extract was brought to a $10-\mathrm{mL}$ 
volume with $80 \%$ ethanol and passed through a C-18 Sep Pak cartridge (Waters/Millipore, Milford, MA) and a $0.45-\mu \mathrm{m}$ Millipore filter. The filtered extract was injected into a Perkin-Elmer series 410 HPLC system (Perkin-Elmer, Norwalk, CT). Levels of fructose, glucose, and sucrose were determined using a Waters Sugar Pak column at $90{ }^{\circ} \mathrm{C}$ with a mobile phase of $100 \mathrm{~mm}$ ethylenediamine-tetraacetic acid disodium-calcium salt and a flow rate of $2 \mathrm{~mL} \cdot \mathrm{min}^{-1}$.

Juice was thawed, mixed, and brought to $25^{\circ} \mathrm{C}$. Juice soluble solids were measured with a refractometer (Bellingham and Stanley, Kent, U.K.). Total acid was determined by titration with $0.3125 \mathrm{~N} \mathrm{NaOH}$ and SSC was calculated by adjusting the ${ }^{\circ}$ Brix for total acids (Davies et al., 2004). Treatment effects on juice SSC were observed at $54 \mathrm{~d}$ after treatment, so $\approx 5 \mathrm{~mL}$ of juice was retained from each of three treated and nontreated samples for determination of sugar composition.

Statistical analyses. Data were initially subjected to analysis of variance using PROC GLM (SAS Institute, Cary, NC). Time and treatment effects were highly significant $(P=$ 0.01). Treatment means and SE were calculated using PROC MEANS (SAS Institute). Some data were subjected to regression analysis using PROC REG (SAS Institute) to examine the relationships between variables.

\section{Results}

Gibberellic ACID TREATMENT AND heXose LeVElS IN THE FLAVEDO. Application of $\mathrm{GA}_{3}$ delayed peel color change (greenest fruit showing highest hue angles along the greenyellow scale in Fig. 1A), and this response was evident as soon as nontreated fruit reached color break. Color differences were apparent at $12 \mathrm{~d}$ after $\mathrm{GA}_{3}$ treatment in Year 1 and at $21 \mathrm{~d}$ after treatment in Year 2. From this point onward, $\mathrm{GA}_{3}$-treated fruit remained consistently more green-colored than nontreated fruit (Fig. 1A). Significant differences in flavedo hexose levels clearly preceded changes in peel color after $\mathrm{GA}_{3}$ treatment in Year 2, confirming similar trends observed in Year 1 (for glucose and fructose in Fig. $1 \mathrm{~B}-\mathrm{C}$, respectively). $\mathrm{GA}_{3}$ treatment rapidly reduced the abundance of fructose and glucose in flavedo tissue of treated compared with nontreated fruit, and differences in levels of glucose, and possibly fructose, may have preceded differences in peel color (Year 1 in Fig. 1B-C). To further resolve timing of sugar changes relative to those of color, sample size was increased in Year 2 (to reduce sample variation), more sample points were used (to define temporal progression), and fruit were treated at a slightly earlier stage of development (to expand observation time). Within $7 \mathrm{~d}, \mathrm{GA}_{3}$ treated fruit had significantly less fructose and glucose in their flavedos than did nontreated fruit (Year 2 in Fig. 1B-C). These differences in sugar content preceded detectable delays in color break (Fig. 1A). In addition, this contrast in hexose abundance persisted throughout the duration of the 58-d study for Year 2, again confirming results obtained for fructose and glucose the previous year (Fig. 1B-C). Initial changes typically resulted in $20 \%$ to $40 \%$ less fructose in flavedo tissue of $\mathrm{GA}_{3}$-treated fruit, but once this difference was established, profiles of change paralleled one another in treated and nontreated fruit. In both groups of fruit, fructose levels in flavedo tissues rose $30 \%$ to $50 \%$ as color change progressed (Fig. 1B). Results were similar for glucose in the flavedo, although overall levels at any given time were typically $20 \%$ to $100 \%$ greater than those of fructose and showed less pronounced changes (Fig. 1C). Purvis and Rice

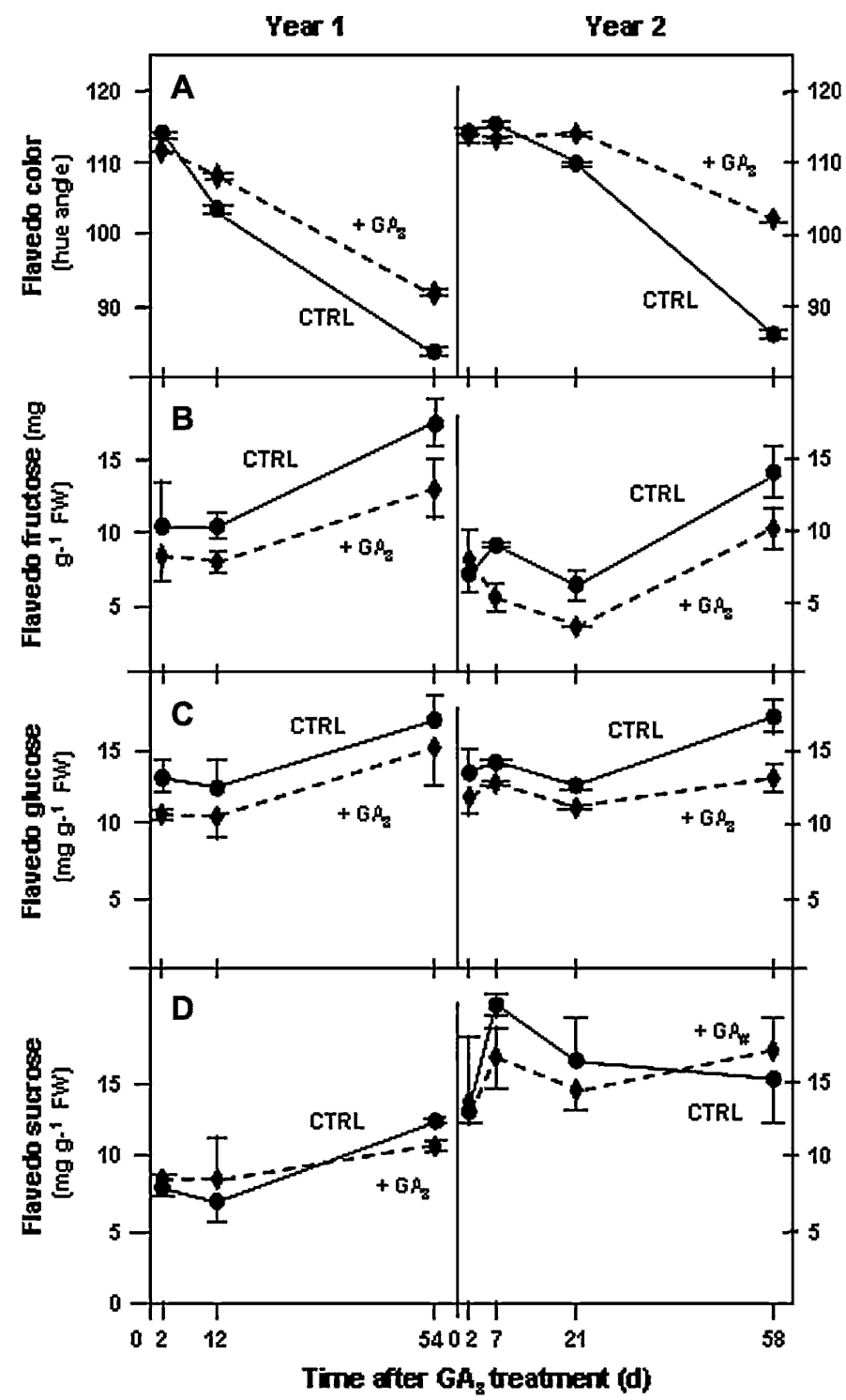

Fig. 1. Color (A) and sugar levels [fructose (B), glucose (C), and sucrose (D)] in flavedo tissue of 'Hamlin' sweet orange fruit sampled at different stages of color development for either nontreated, control fruit or those receiving a precolor-break treatment of gibberellic acid at Day 0 (6 Oct. for Year 1, 2 Oct. for Year 2). Greenest fruit are shown with highest hue angles along the greenyellow axis in (A). Sampling dates were based on development of nontreated fruit and progressed during Year 1 from green at $2 \mathrm{~d}$ after treatment to color break at $12 \mathrm{~d}$ after treatment and yellow at $54 \mathrm{~d}$ after treatment. During Year 2, fruit were green at $2 \mathrm{~d}$ after treatment, remained at precolor break $7 \mathrm{~d}$ after treatment, had reached color break by $21 \mathrm{~d}$ after treatment, and were yellow at $58 \mathrm{~d}$ after treatment. Values are treatment means \pm SE based on a sample of five fruit from each of three (Year 1 and Year 2) or four trees (Year 2) per treatment.

(1983) observed similar overall trends in grapefruit flavedos, in which reducing sugars decreased slightly from October to November before increasing markedly in December and January.

Flavedo sucrose levels were variable $\left(7.4\right.$ to $20.7 \mathrm{mg} \cdot \mathrm{g}^{-1}$ fresh weight) but generally increased as the peel matured (Fig. 1D). Data were comparable with results of Komatsu et al. (2002) and Iglesias et al. (2001) for flavedo tissue of satsuma mandarin fruit (Citrus unshiu Marc.). Treatment effects on sucrose levels were few and inconsistent. Glucose (Fig. 2A) and fructose (Fig. 2B), but not sucrose (Fig. 2C), showed a consistent inverse linear relationship with peel color. Flavedo 


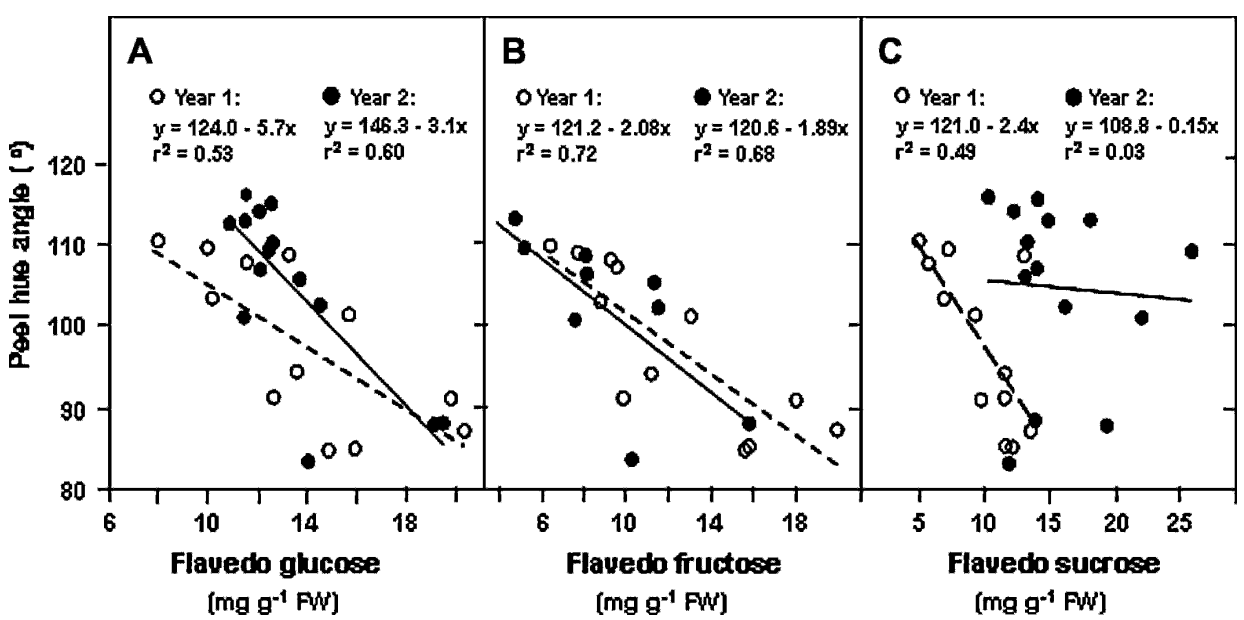

Fig. 2. Relationship between peel color (hue angle values indicate green-yellow balance) and flavedo sugar level [glucose (A), fructose (B), or sucrose (C)] during maturation of 'Hamlin' sweet orange fruit sampled at different stages of color development for either nontreated control fruit or those receiving a precolor-break treatment of gibberellic acid at Day 0 (6 Oct. for Year 1, 2 Oct. for Year 2). Greenest fruit are shown with highest hue angles along the green-yellow axis. Sampling dates were based on development of nontreated fruit and had progressed during Year 1 to color break at $12 \mathrm{~d}$ after treatment and yellow at $54 \mathrm{~d}$ after treatment. During Year 2, fruit had reached color break by $21 \mathrm{~d}$ after treatment and were yellow at $58 \mathrm{~d}$ after treatment. Regression analysis was based on pooled data from all harvest dates during each year.

not others (Davies and Zalman, 2006). The basis for variable effects of $\mathrm{GA}_{3}$ on juice SSC is unclear. The composition of juice soluble solids from treated and nontreated fruit was approximately the same each year (50\% sucrose, $30 \%$ fructose, and $20 \%$ glucose).

\section{Discussion}

Peel sugars affect gibberellic ACID DELAYS IN COLOR BREAK. Flavedo hexoses, in particular, were implicated in color break delay by their rapid response to $\mathrm{GA}_{3}$ and by the correlation between these hexose levels and color development. The influence of $\mathrm{GA}_{3}$ on maintenance of sucrose gradients from the albedo to flavedo tissues may also be involved, but these effects emerged more slowly.

A key line of evidence for contributions by flavedo hexoses is that $\mathrm{GA}_{3}$ decreased levels of these sugars rela-

sucrose levels also were inversely related to green color in the first year, but this was not evident the second year (Fig. 2D). In general, fruit respiration was low (5 to $12 \mathrm{mg} \mathrm{CO}_{2}$ per kilogram per hour) and there were no significant treatment effects (data not shown).

GibBERELLIC ACID DELAYEd CHANGES IN ALBEDo SUGARs. In contrast with the flavedo, sucrose levels in the albedo were generally greatest at the earliest harvest dates, when the flavedo was still green. Albedo sucrose levels tended to decrease as the flavedo began to change color (Fig. 3A). Where color break was most strongly delayed $\left(\mathrm{GA}_{3}\right.$-treated fruit during Year 2), albedo sucrose levels were relatively constant. In both years, $\mathrm{GA}_{3}$ treatment limited the extent of sucrose loss from albedo tissue during development such that albedo sucrose levels remained greater than those of nontreated fruit.

At the same time, mean fructose and glucose levels in albedo tissue of nontreated fruit showed little change or increased to varying degrees during color development of the flavedo (Fig. $3 \mathrm{~B}-\mathrm{C}$ ). Where responses to $\mathrm{GA}_{3}$ treatment were evident in albedo hexoses (Year 2), levels decreased relative to controls [long-term for fructose (Fig. 3B) and short-term for glucose (Fig. 3C)].

GIBBERELLIC ACID-TREATED FRUIT AND SUCROSE GRADIENTS. The $\mathrm{GA}_{3}$ application helped maintain a descending sucrose gradient from the albedo to the flavedo tissues (Fig. 4A-B). The presence of this gradient coincided with that of green color in the flavedo and dissipated as fruit turned yellow (rapidly for nontreated fruit and more slowly after $\mathrm{GA}_{3}$-treated fruit). In Year 2, $\mathrm{GA}_{3}$-treated fruit had not become fully yellow by the end of the experiment, and their albedo-to-flavedo sucrose gradient remained intact. The $\mathrm{GA}_{3}$-treated and nontreated fruit had generally similar total sugars in the endocarp (juice tissues) at each harvest date in Year 1. However, in the second year, when nontreated fruit were yellow, their mean SSC was greater than that of treated fruit $(9.1 \%$ and $8.4 \%$, respectively). The timing and magnitude of the second-year response is consistent with some previous studies (Coggins et al., 1960; Fidelibus et al., 2002; Monselise and Goren, 1965; Pozo et al., 2000), but tive to nontreated controls before delaying color break (Fig. 1A-C). In Year 1, differences in peel color were not yet evident at $2 \mathrm{~d}$ after treatment (Fig. 1A), but by this time, flavedo glucose levels were already significantly less than those of nontreated controls (Fig. 1C). In Year 2, detectable color break delay was again apparent only after significant decreases had occurred in flavedo hexoses relative to nontreated fruit (both glucose and fructose in this instance) (Fig. 1A-C). This timing is consistent with participation of hexoses as contributing intermediates in the action of $\mathrm{GA}_{3}$ on color break and also with the initial suggestion by Huff (1984) that overall levels of soluble sugars in the peel could modulate its color. In addition, the progression observed here, and that of $\mathrm{GA}_{3}$ responses by genes in mandarin fruit (Fujii et al., 2008), is compatible with regulation of genes for photosynthesis and chloroplast pigment biosynthesis by sugars as defined in other systems (Koch, 1996; Pourtau et al., 2006; Price et al., 2004; Rolland et al., 2006).

The rapid hexose responses to $\mathrm{GA}_{3}$ treatment (less than 2 or $7 \mathrm{~d}$ ) also persisted over time and were consistent with results of previous, longer-term studies. Monselise and Goren (1965), for example, found that two applications of $\mathrm{GA}_{3}$ in the fall could reduce hexose levels in the flavedo of winter-harvested 'Shamouti' sweet orange, but data were not available for shorter-term responses. Later work by Kuraoka et al. (1977) showed that one and two applications of $\mathrm{GA}_{3}$ at about the time of color break could suppress total soluble sugar accumulation in the flavedo of satsuma mandarin fruit within $14 \mathrm{~d}$ of application. Furthermore, Goldschmidt et al. (1977) reported that within $2 \mathrm{~d}$ of ethylene treatment, fruit accumulated $\approx 20 \%$ more hexoses in their flavedos than fruit treated first with $\mathrm{GA}_{3}$ and than ethylene. Additional work by Iglesias et al. (2001) demonstrated that $\mathrm{GA}_{3}$ could counter effects of supplemental sugars for at least $10 \mathrm{~d}$ in vitro and $\approx 90 \mathrm{~d}$ in vivo. We showed that initial hexose responses to $\mathrm{GA}_{3}$ occurred in less than 2 or $7 \mathrm{~d}$, that these were evident at or before differences in fruit color, and that $\mathrm{GA}_{3}$-based alterations in sugar levels persisted throughout the 54- or 58-d study. 


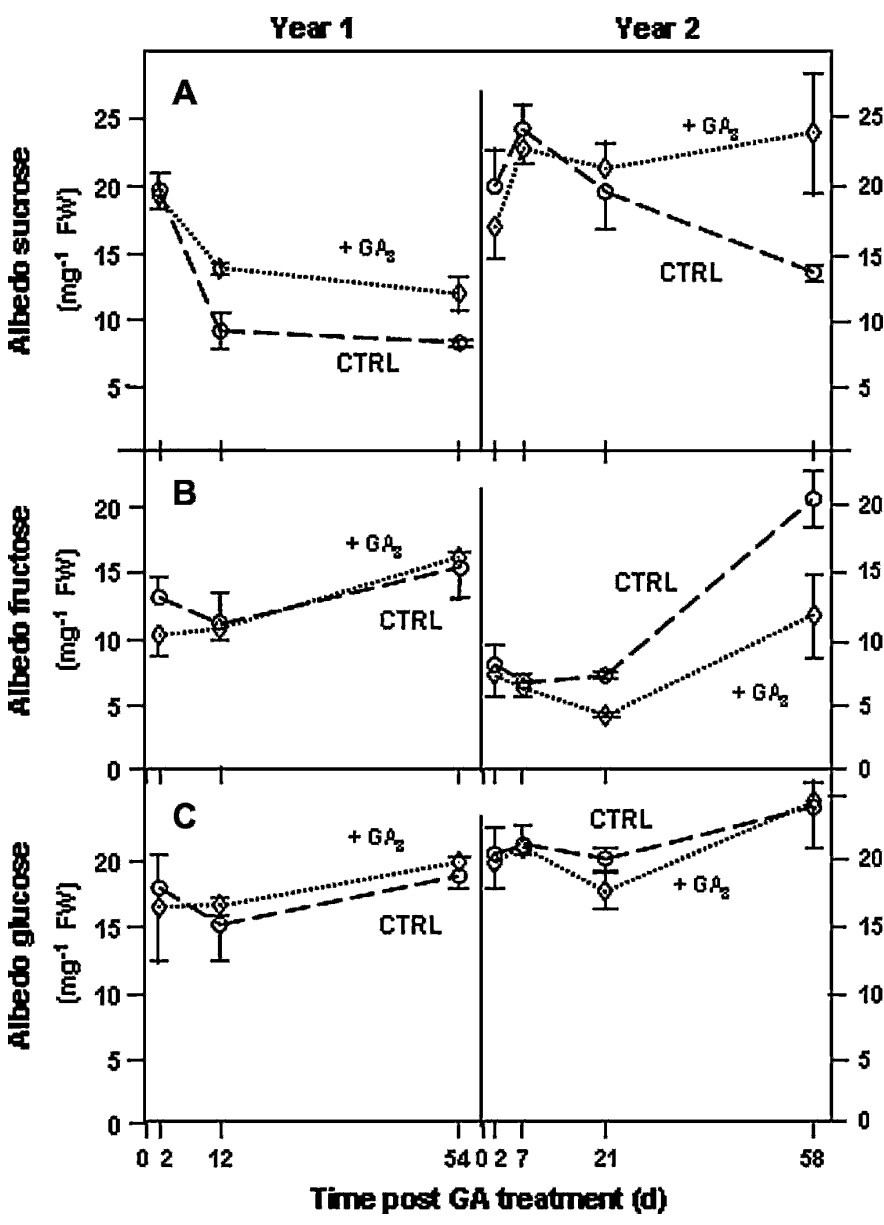

Fig. 3. Levels of sucrose (A) and fructose (B) in the albedo during maturation of 'Hamlin' sweet orange fruit sampled at different stages of development for either nontreated control fruit or those receiving a precolor-break treatment of gibberellic acid on Day 0 (6 Oct. for Year 1, 2 Oct. for Year 2). Sampling dates were based on development of nontreated fruit and progressed during Year 1 from green at $2 \mathrm{~d}$ after treatment to color break at $12 \mathrm{~d}$ after treatment and yellow at $54 \mathrm{~d}$ after treatment. During Year 2, fruit were green at $2 \mathrm{~d}$ after treatment, remained at precolor break $7 \mathrm{~d}$ after treatment, had reached color break by $21 \mathrm{~d}$ after treatment, and were yellow at $58 \mathrm{~d}$ after treatment. Values are treatment means \pm SE based on a sample of five fruit from each of three (Year 1) or four (Year 2) trees per treatment.

A longer-term involvement of flavedo hexoses (although not flavedo sucrose) was also indicated by analysis of correlations between these sugars and peel color during the transitions examined here for $\mathrm{GA}_{3}$-treated and nontreated fruit (Fig. 2). For data points taken after the treatment had altered peel color, an inverse, linear relationship was evident between the degree of greenness (high hue angle) and levels of flavedo hexoses (Fig. 2A-B). Although a similar relationship was observed here for total soluble sugar levels in flavedo tissue (data not shown) and previously for the peel overall (Huff, 1984; Iglesias et al., 2001), results indicated a prominent role for the hexose constituents in particular (Figs. 1 and 2). The relationship between hexoses and degree of greenness was less variable at high peel hue angles (more green peel color) and low soluble sugar levels as might be expected if genes for photosynthesis were upregulated by an absence of abundant soluble sugars (Fig. 2A-B) (Koch, 1996; Pourtau et al., 2006; Rolland et al., 2006). This observation agrees with data suggesting that gibberellin activity of 'Valencia' orange flavedo tissue
Year 1

Year 2

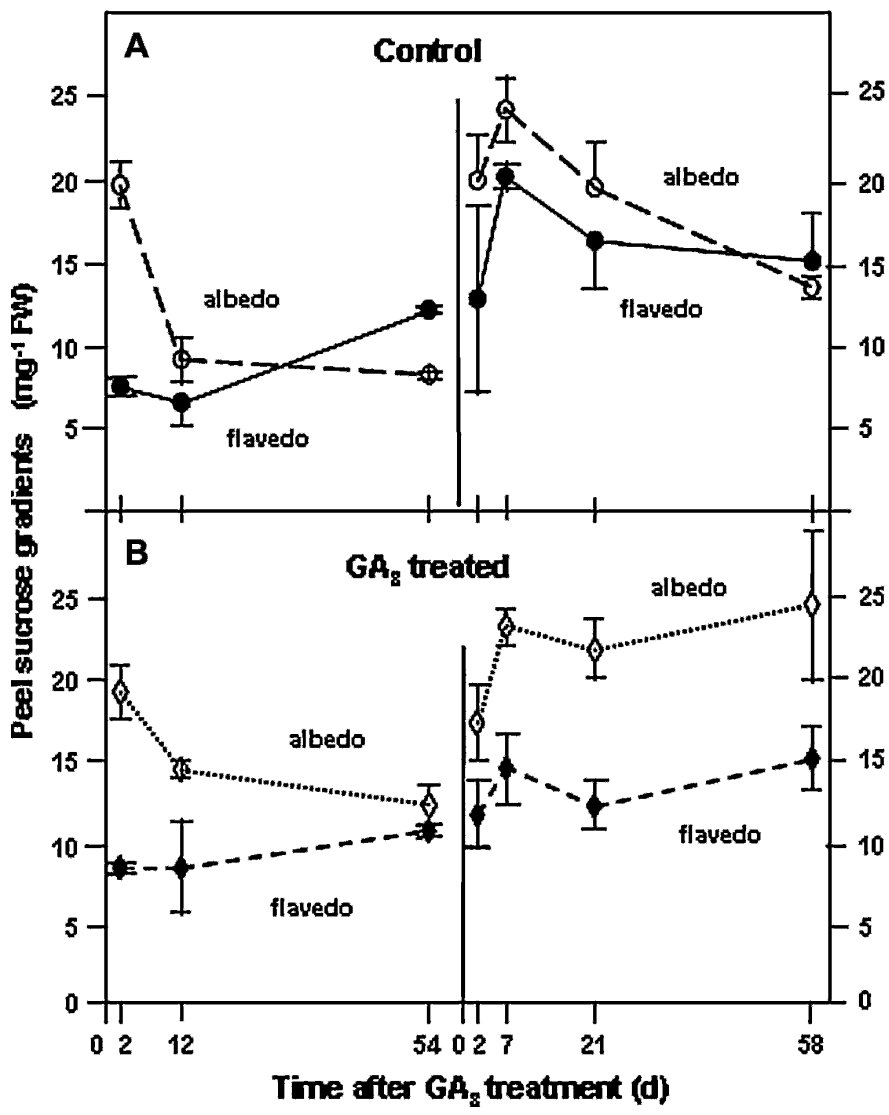

Fig. 4. Peel sucrose gradients between the albedo and the flavedo during maturation of 'Hamlin' sweet orange fruit sampled at different stages of development from either (A) nontreated control fruit or (B) those receiving a precolor-break treatment of gibberellic acid at Day 0 (6 Oct. for Year 1, 2 Oct. for Year 2). Sampling dates were based on development of nontreated fruit and progressed during Year 1 from green at $2 \mathrm{~d}$ after treatment to color break at $12 \mathrm{~d}$ after treatment and yellow at $54 \mathrm{~d}$ after treatment. During Year 2, fruit were green at $2 \mathrm{~d}$ after treatment, remained at precolor break $7 \mathrm{~d}$ after treatment, had reached color break by $21 \mathrm{~d}$ after treatment, and were yellow at $58 \mathrm{~d}$ after treatment. Values are treatment means $\pm \mathrm{SE}$ based on a sample of five fruit from each of three (Year 1) or four trees (Year 2) per treatment.

increased (Rasmussen, 1973) and soluble sugar levels decreased before regreening (Huff, 1984).

Hexoses mediate responses to gibBerellic aCID. One mode of action for $\mathrm{GA}_{3}$ on flavedo color break could be the relatively rapid effect of this treatment on hexose levels, which are known to regulate many processes involved in the chloroplast-to-chromoplast conversion. Such a role for hexoses would also be consistent with the greater responsiveness of many sugar-regulated genes to hexose sugars such as fructose and glucose rather than to sucrose (Koch, 1996; Rolland et al., 2006). A prominent hexose-sensing system (operating through dual roles of hexokinase) is now well documented in its capacity to control gene expression for chlorophyll biosynthesis, photosynthesis, senescence, and plastid conversions (Pourtau et al., 2006; Rolland et al., 2006), all of which are likely involved in color break.

In addition, changes in hexose levels such as observed here are now known to have other effects on signal systems that could provide diverse avenues of input into color break. One of these is the influence of glucose and fructose on gene expression for biosynthesis and perception of hormones such as ABA 
(Rognoni et al., 2007; Rolland et al., 2006) and interaction with ethylene (Price et al., 2004; Rognoni et al., 2007) through the hexose-sensing system noted previously. Another is the potential for at least some instances of direct competition between $\mathrm{GA}_{3}$ and sugars as evidenced by their contrasting action through a shared regulatory motif in an alpha-amylase gene (Lu et al., 2002). Finally, hexose responses to $\mathrm{GA}_{3}$ treatment have the potential to affect all three currently known mechanisms for plastid signaling to the nucleus, a process central to the chloroplast-to-chromoplast conversion occurring during color break (Koussevitzky et al., 2007).

RAPID EFFECTS OF GIBBERELLIC ACID WERE LOCALIZED IN THE FLAVEDO. Separate analysis of the green flavedo and white albedo provided additional insight into the functioning of the citrus peel and its dual status as both a source and sink. The $\mathrm{GA}_{3}$-based hexose differences noted previously were localized largely to the photosynthetic flavedo, and so too were the most rapid changes in sugars (Figs. 1, 3, and 4). These results for flavedo tissue differed from the whole-organ responses to $\mathrm{GA}_{3}$ typical of young citrus fruit (Berhow, 2000; Fidelibus et al., 2002; Kubo and Hiratsuka, 2000) and growing fruit of other species (Cano-Medrano and Darnell, 1997; Estruch and Beltran, 1991; Perez and Gomez, 2000; Zhang et al., 2007). Treatments with $\mathrm{GA}_{3}$ typically increase size and/ or alter shape of young fruit (El-Otmani et al., 2000; Martin, 1983), concurrently increasing hexose levels (Cano-Medrano and Darnell, 1997; Estruch and Beltran, 1991; Perez and Gomez, 2000). Instead, hexose levels measured here for flavedo tissue of $\mathrm{GA}_{3}$-treated fruit were less rather than greater (Fig. 1), possibly as a result of the fully expanded status of the fruit and/ or the flavedo capacity as a photosynthetic source tissue (Huang et al., 1992; Yen and Koch, 1990).

One possibility for the rapid decreases in flavedo hexose levels is that $\mathrm{GA}_{3}$ could have depleted the abundance of glucose and fructose by increasing their respiratory use. This suggestion is consistent with early work by Lewis et al. (1967) who reported that $\mathrm{GA}_{3}$-treated citrus peel used more glucose than nontreated peel. However, these researchers were unable to detect respiratory differences between treated and nontreated fruit in either fall or winter. Goldschmidt et al. (1977) found that $\mathrm{GA}_{3}$ somewhat reduced respiratory rises that occur with ethylene treatment of citrus fruit. In addition, treatment with 1-methylcyclopropene, another means of countering ethyleneenhanced color break, initially elevates $\mathrm{CO}_{2}$ release but later reduces carbon losses that accompany ethylene application (McCollum and Maul, 2007). Our data did not support a respiratory increase in response to $\mathrm{GA}_{3}$ treatment, because rates were generally similar in treated and nontreated fruit. However, results shown here do not rule out the possible involvement of short-term changes in $\mathrm{CO}_{2}$ exchange or a potential role for fruit photosynthesis in response to $\mathrm{GA}_{3}$.

Because the flavedo is an active source tissue (Huang et al., 1992; Yen and Koch, 1990), its $\mathrm{GA}_{3}$ responses may share important commonalities with those reported for other photosynthetic structures (Cheikh et al., 1992). Treatments with $\mathrm{GA}_{3}$ enhance export capacity of diverse source tissues that include not only photosynthetic leaves (Cheikh et al., 1992), but also aleurone and scutella of germinating grains (Lu et al., 2002). If true for the flavedo as well, then at least some of the sucrose synthesis and export from this tissue could initially have occurred at the expense of accumulated hexoses. Such a scenario would also be compatible with recent observations that $\mathrm{GA}_{3}$ upregulates genes for photosynthesis in mature mandarin fruit (Fujii et al., 2008) and that changes occur sometime before $3 \mathrm{~d}$ after treatment. In addition, $\mathrm{GA}_{3}$ responses are typically rapid in the photosynthetic leaves and result in elevated capacity for sucrose synthesis through SPS within only $2 \mathrm{~h}$ (Cheikh et al., 1992). This SPS induction by $\mathrm{GA}_{3}$ also persists for at least $7 \mathrm{~d}$ in leaves, consistent with a potential for rapid but long-term effects on export. A possible enhancement of sucrose export from the flavedo need not necessarily be reflected in whole-fruit $\mathrm{CO}_{2}$ exchange, because a small increase in transfer could account for differences in flavedo and albedo sugars during the timeframes observed here. Also relevant to flavedo sugar status is the potential for perturbation of the balance between soluble sugars and chloroplast starch. This can occur within $3 \mathrm{~h}$ of other treatments that alter color change in this tissue (e.g., color break enhancement with 5-chloro-3-methyl-4-nitro-1H-pyrazole) (Alferez et al., 2006).

GibBERELLIC ACID MAINTAINED SUCROSE GRADIENTS IN THE PEEL. An intriguing aspect of the $\mathrm{GA}_{3}$ response observed here was that the consistent reduction in sucrose depletion from the albedo (Fig. 3) resulted in maintenance of a descending sucrose gradient from albedo to flavedo (Fig. 4). This gradient dissipated during color break in nontreated fruit. The greater abundance and gradients of sucrose were typical of young, more actively importing fruit (Koch and Avigne, 1990; Yen and Koch, 1990). As noted previously, the albedo sucrose could have been imported from flavedo tissue as well as photosynthetic leaves (Huang et al., 1992; Yen and Koch, 1990). Leaves typically predominate as sources of sucrose for juice sacs and albedo of citrus fruit, but the flavedo can also synthesize and export significant amounts of sucrose to the albedo and some to juice sacs (Yen and Koch, 1990). Regardless of whether sugars originate in leaves or the flavedo, their entry into juice sacs typically proceeds up an ascending gradient in young fruit and down a descending gradient in fully expanded fruit (Koch and Avigne, 1990). The descending gradient is established as sugars rise to maximal levels in segment epidermis and associated tissues, a transition that may have been delayed by sucrose retention in the albedo of $\mathrm{GA}_{3}$ treated fruit. Such a scenario may or may not have affected juice tissues but provides a possible explanation of how $\mathrm{GA}_{3}$ could affect juice sugars without leaving the peel tissues as per long-term radiolabeling studies of Ferguson et al. (1986).

\section{Conclusions}

Several hypotheses have been advanced to help explain effects of $\mathrm{GA}_{3}$ on color break of citrus fruit. We propose that these $\mathrm{GA}_{3}$ responses are at least partially mediated or enhanced by depletion of flavedo hexoses. Supporting evidence in this study includes the observation that $\mathrm{GA}_{3}$ application consistently reduced flavedo fructose and glucose levels below those of nontreated controls and did so before delaying color break. The timing of these events is consistent with at least one mode of $\mathrm{GA}_{3}$ action being an initial effect on flavedo sugars. In addition, specificity of the association between fruit color and flavedo hexoses was further substantiated by inverse correlations between the extent of green color retention and levels of fructose or glucose, but not sucrose, in the flavedo. Opposite responses and relationships were evident for albedo tissue in which $\mathrm{GA}_{3}$ treatment delayed sucrose depletion and maintained descending gradients from albedo-to-flavedo tissues. These 
features were consistent with a prolonged role for the albedo as a transient reservoir for sucrose typical of young fruit. This sugar status of the albedo may be indirectly related to that of the flavedo and possibly juice tissues.

\section{Literature Cited}

Alferez, F., L. Pozo, and J.K. Burns. 2006. Physiological changes associated with senescence and abscission in mature citrus fruit induced by 5-chloro-3-methyl-4-nitro-1H-pyrazole and ethephon application. Physiol. Plant. 127:66-73.

Baldwin, E.A., M.O. Nisperos-Carriedo, and M.G. Moshonas. 1991. Quantitative analysis of flavor and other volatiles and for certain constituents of two tomato cultivars during ripening. J. Amer. Soc. Hort. Sci. 116:265-269.

Berhow, M.A. 2000. Effects of early plant growth regulator treatments on flavonoid levels in grapefruit. Plant Growth Regulat. 3:225-232. Cano-Medrano, R. and R.L. Darnell. 1997. Sucrose metabolism and fruit growth in parthenocarpic vs seeded blueberry (Vaccinium ashei) fruits. Physiol. Plant. 99:439-446.

Cheikh, N., M.L. Brenner, J.L. Huber, and S.C. Huber. 1992. Regulation of sucrose phosphate synthase by gibberellins in soybean and spinach plants. Plant Physiol. 100:1238-1242.

Coggins, C.W. 1969. Gibberellin research on citrus rind aging problems. Proc. First Intl. Citrus Symp. 3:1177-1185.

Coggins, C.W., H.Z. Hield, and M.J. Garber. 1960. The influence of potassium gibberellate on Valencia orange trees and fruit. Proc. Amer. Soc. Hort. Sci. 76:193-198.

Davies, F.S. 1986. Growth regulator improvement of postharvest quality, p. 79-99. In: Wardowski, W., S. Nagy, and W. Grierson (eds.). Fresh citrus fruit. AVI Press, Westport, CT.

Davies, F.S., E. Stover, G. Zalman, and S. Ciliento. 2004. Ecolyst application timing and juice Brix of processing oranges and grapefruit in Florida. HortTechnology 14:207-212.

Davies, F.S. and G. Zalman. 2006. Gibberellic acid, fruit freezing, and post-freeze quality of 'Hamlin' oranges. HortTechnology 16:301-305.

El-Otmani, M., C.W. Coggins, M. Agusti, and C.J. Lovatt. 2000. Plant growth regulators in citriculture: World current uses. Crit. Rev. Plant Sci. 19:395-447.

Erickson, L.C. 1968. The general physiology of citrus, p. 86-126. In: Reuther, W., L.D. Batchelor, and H.J. Webber (eds.). The citrus industry. Vol. II. Univ. Calif., Berkeley, CA.

Estruch, J.J. and J.P. Beltran. 1991. Changes in invertase activities precede ovary growth induced by gibberellic acid in pea. Physiol. Plant. 81:319-326.

Ferguson, L., T.A. Wheaton, F.S. Davies, and M.A. Ismail. $1986 .{ }^{14}$ Cgibberellic acid uptake, translocation, persistence and metabolism in grapefruit. J. Amer. Soc. Hort. Sci. 111:926-932.

Fidelibus, M.W., F.S. Davies, and C.A. Campbell. 2002. Gibberellic acid application affects fruit quality of processing oranges. HortScience 37:353-357.

Fujii, H., T. Shimada, A. Sugiyama, T. Endo, F. Nishikawa, M. Nakano, Y. Ikoma, T. Shimizua, and M. Omura. 2008. Profiling gibberellin [GA(3)]-responsive genes in mature mandarin fruit using a citrus 22K oligoarray. Scientia Hort. 3:291-298.

Goldschmidt, E.E., Y. Aharoni, S.K. Eilati, J.W. Riov, and S.P. Monselise. 1977. Differential counteraction of ethylene effects by gibberellin A3 and N6-benzyladenine in senescing citrus peel. Plant Physiol. 59:193-195.

Goldschmidt, E.E. and K.E. Koch. 1996. Citrus, p. 797-823. In: Zamski, E., and A.A. Schaffer (eds.). Photoassimilate distribution in plants and crops: Source-sink relationships. Marcel Dekker, New York, NY.

Goudeau, D., S.L. Uratsu, K. Inoue, F.G. Dasilva, A. Leslie, D. Cook, R.L. Reagan, and A.M. Dandekar. 2008. Tuning the orchestra: Selective gene regulation and orange fruit quality. Plant Sci. 174:310-320.

Huang, T.B., R.L. Darnell, and K.E. Koch. 1992. Water and carbon budgets of developing citrus fruit. J. Amer. Soc. Hort. Sci. 117:287-293.
Huff, A. 1984. Sugar regulation of plastid interconversions in epicarp of citrus fruit. Plant Physiol. 76:307-312.

Iglesias, D.J., F.R. Tadeo, F. Legaz, E. Primo-Millo, and M. Talon. 2001. In vivo sucrose stimulation of colour change in citrus fruit epicarps: Interactions between nutritional and hormonal signals. Physiol. Plant. 112:244-250.

Koch, K.E. 1996. Carbohydrate modulated gene expression in plants. Annu. Rev. Plant Physiol. Plant Mol. Biol. 47:509-540.

Koch, K.E. and W.T. Avigne. 1990. Postphloem, nonvascular transfer in citrus: Kinetics, metabolism, and sugar gradients. Plant Physiol. 93:1405-1416.

Komatsu, A., T. Moriguchi, K. Koyama, M. Omura, and T. Akihama. 2002. Analysis of sucrose synthase genes in citrus suggests different roles and phylogenetic relationships. J. Expt. Bot. 53:61-71.

Koussevitzky, S., A. Nott, T.C. Mockler, F. Hong, G. SachettoMartins, M. Surpin, J.R. Mittler, and J. Chory. 2007. Multiple signals from damaged chloroplasts converge to regulate nuclear gene expression. Science 316:715-719.

Kubo, T. and S. Hiratsuka. 2000. Relationship between rind roughness and gibberellins in satsuma mandarin fruit. J. Jpn. Soc. Hort. Sci. 69:718-723.

Kuraoka, T., I. Kazuo, and I. Takaaki. 1977. Effects of $\mathrm{GA}_{3}$ on puffing and levels of GA-like substances and ABA in the peel of satsuma mandarin (Citrus unshiu Marc.). J. Amer. Soc. Hort. Sci. 102:651654.

Lewis, L.N., C.W. Coggins, C.K. Labanauskas, and D.M. Dugger. 1967. Biochemical changes associated with natural and gibberellin $\mathrm{A}_{3}$ delayed senescence in the navel orange rind. Plant Cell Physiol. 8:151-160.

Loreti, E., G. Povero, G. Novi, C. Solfanelli, A. Alpi, and P. Perata. 2008. Gibberellins, jasmonate and abscisic acid modulate the sucrose-induced expression of anthocyanin biosynthetic genes in Arabidopsis. New Phytol. in press.

Lu, C.A., T.H.D. Ho, S.L. Ho, and S.M. Yu. 2002. Three novel MYB proteins with one DNA binding repeat mediate sugar and hormone regulation of alpha-amylase gene expression. Plant Cell 14:19631980.

Martin, G.C. 1983. Commercial uses of gibberellins, p. 395-444. In: Crozier, A. (ed.). The biochemistry and physiology of gibberellins. Praeger, New York, NY.

McCollum, G. and P. Maul. 2007. 1-Methylcyclopropene inhibits degreening but stimulates respiration and ethylene biosynthesis in grapefruit. HortScience 42:120-124.

McDonald, R.E., P.D. Greany, and T.G. McCollum. 1997. Preharvest applications of gibberellic acid delay senescence of Florida grapefruit. J. Hort. Sci. 72:461-468.

Monselise, S.P. and R. Goren. 1965. Changes in composition and enzymatic activity in flavedo of Shamouti oranges during the color break period, as influenced by application of gibberellin and 2chloroethyl trimethyl-ammonium chloride. Phyton 22:61-66.

Perez, F.J. and M. Gomez. 2000. Possible role of soluble invertase in the gibberellic acid berry-sizing effect in Sultana grape. Plant Growth Regulat. 30:111-116.

Pourtau, N., R. Jennings, E. Pelzer, J. Pallas, and A. Wingler. 2006. Effect of sugar-induced senescence on gene expression and implications for the regulation of senescence in Arabidopsis. Planta 224:556-568.

Pozo, L., W.J. Kender, J.K. Burns, U. Hartmond, and A. Grant. 2000. Effects of gibberellic acid on ripening and rind puffing in 'Sunburst' mandarin. Proc. Florida State Hort. Soc. 113:102-105.

Price, J., A. Laxmi, S.K. St Martin, and J.C. Jang. 2004. Global transcription profiling reveals multiple sugar signal transduction mechanisms in Arabidopsis. Plant Cell 16:2128-2150.

Purvis, A.C. and J.D. Rice. 1983. Low temperature induction of invertase activity in grapefruit flavedo tissue. Phytochemistry 22:831-834.

Rasmussen, G.K. 1973. The effect of growth regulators on degreening and regreening of citrus fruit. Acta Hort. 34:473-478. 
Rodrigo, M.J. and L. Zacarias. 2007. Effect of postharvest ethylene treatment on carotenoid accumulation and the expression of carotenoid biosynthetic genes in the flavedo of orange (Citrus sinensis L. Osbeck) fruit. Postharvest Biol. Technol. 43:14-22.

Rognoni, S., S. Teng, L. Arru, S.C.M. Smeekens, and P. Perata. 2007. Sugar effects on early seedling development in Arabidopsis. Plant Growth Regulat. 52:217-228.

Rolland, F., E. Baena-Gonzalez, and J. Sheen. 2006. Sugar sensing and signaling in plants: Conserved and novel mechanisms. Annu. Rev. Plant Biol. 57:675-709.
Thomson, W.W., L.N. Lewis, and C.W. Coggins. 1967. The reversion of chromoplasts to chloroplasts in Valencia oranges. Cytologia (Tokyo) 32:117-124.

Yen, C.R. and K.E. Koch. 1990. Developmental changes in translocation and localization of ${ }^{14} \mathrm{C}$-labeled assimilates in grapefruit: Light and dark $\mathrm{CO}_{2}$ fixation by leaves and fruit. J. Amer. Soc. Hort. Sci. 115:815-819.

Zhang, C.X., K. Tanabe, F. Tamura, A. Itai, and M. Oshida. 2007. Roles of gibberellins in increasing sink demand in japanese pear fruit during rapid fruit growth. Plant Growth Regulat. 52:161-172. 